\title{
Leaders
}

\section{New insights into the role of cytokines in asthma}

\author{
J-C Renauld
}

\begin{abstract}
Asthma is a triad of intermittent airway obstruction, bronchial smooth muscle cell hyperreactivity to bronchoconstrictors, and chronic bronchial inflammation. From an aetiological standpoint, asthma is a heterogenous disease, but often appears as a form of immediate hypersensitivity. Many patients with asthma have other manifestations of atopy, such as rhinitis or eczema. Even among nonatopic patients with asthma, the pathophysiology of airway constriction is similar, raising the hypothesis that alternative mechanisms of mast cell degranulation may underlie the disease. The primary inflammatory lesion of asthma consists of accumulation of $\mathrm{CD}^{+} \mathrm{T}$ helper type 2 (TH2) lymphocytes and eosinophils in the airway mucosa. TH2 cells orchestrate the asthmatic inflammation through the secretion of a series of cytokines, particularly interleukin 4 (IL-4), IL-13, IL-5, and IL-9. IL-4 is the major factor regulating IgE production by $B$ cells, and is
\end{abstract} required for optimal TH2 differentiation. However, blocking IL-4 is not sufficient to inhibit the development of asthma in experimental models. In contrast, inhibition of IL-13, another TH2 cytokine whose signal transduction pathway overlaps with that of IL-4, completely blocks airway hyperreactivity in mouse asthma models. IL-5 is a key factor for eosinophilia and could therefore be responsible for some of the tissue damage seen in chronic asthma. IL-9 has pleiotropic activities on allergic mediators such as mast cells, eosinophils, $B$ cells and epithelial cells, and might be a good target for therapeutic interventions. Finally, chemokines, which can be produced by many cell types from inflamed lungs, play a major role in recruiting the mediators of asthmatic inflammation. Genetic studies have demonstrated that multiple genes are involved in asthma. Several genome wide screens point to chromosome 5q31-33 as a major susceptibility locus for asthma and high IgE values. This region includes a cluster of cytokine genes, and genes encoding IL-3, IL-4, IL-5, IL-9, IL-13, granulocyte macrophage colony stimulating factor, and the $\beta$ chain of IL-12. Interestingly, for some of these cytokines, a linkage was also established between asthma and their receptor. Another susceptibility locus has been mapped on chromosome 12 in a region that contains other potential candidate cytokine genes, including the gene encoding interferon $\gamma$, the prototypical TH1 cytokine with inhibitory activities for TH2 lymphocytes. Taken together, both experimental and genetic studies point to TH2 cytokines, such as IL-4, IL-13, IL-5, and IL-9, as important targets for therapeutic applications in patients with asthma. (F Clin Pathol 2001;54:577-589)

Keywords: asthma; cytokines; interleukins; treatment of asthma; interferon $\gamma$

Asthma is one of the most common disorders encountered in clinical medicine in both children and adults. It affects approximately $5 \%$ of the adult population in the Western world and its reported incidence is increasing dramatically in many developed nations. The cost of the disease is substantial, and the market for the pharmaceutical industry is estimated at $\$ 5.5$ billion/year. ${ }^{12}$ Rather than being a single disease, asthma is currently considered to be a group of different disorders characterised by three major features: (1) intermittent and reversible airway obstruction leading to recurrent episodes of wheezing, breathlessness, chest tightness, and cough; (2) bronchohyperresponsiveness (BHR), which is defined as an increased sensitivity to bronchoconstrictors such as histamine or cholinergic agonists; and (3) airway inflammation.

This syndrome arises as a result of interactions between multiple genetic and environmental factors. ${ }^{1}$ Most patients also exhibit acute immediate hypersensitivity responses to common inhaled proteins, known as allergens, of which very small amounts trigger $\operatorname{IgE}$ dependent mast cell degranulation, leading to reversible airway obstruction. Typical allergen sources include grass pollens and animal danders, but the most important to those with asthma is house dust mite. ${ }^{2}{ }^{3}$ However, a large proportion of patients with asthma present with no personal or family history of allergy, with negative skin tests, and with normal serum concentrations of $\mathrm{IgE}$, and therefore have disease that cannot be classified on the basis of defined immunological mechanisms. In these non-atopic patients, the pathophysiology of 
airway constriction has some similarities, including eosinophil and $\mathrm{T}$ helper type 2 (TH2) lymphocyte infiltration, the presence of FceRI+ cells, and cells expressing IgE mRNA. ${ }^{4}$ In a series of biopsies from atopic or non-atopic patients with asthma, the main difference was a stronger macrophage infiltration in non-atopic asthma, although there were more similarities than differences between these subgroups of patients. Both forms of the disease could be IgE mediated, although in non-atopic patients the putative antigen is unknown, and IgE production appears to be local rather than generalised as in atopy. ${ }^{4}$ Alternative mechanisms of mast cell degranulation (for example, by locally produced neurotransmitters) may also underlie this disease. However, the origin of non-atopic asthma remains highly controversial, and mast cell independent mechanisms could play a major role in a subgroup of patients.

Work over the past 10 years led to the recognition that chronic inflammation underlies the clinical syndrome of asthma. ${ }^{56}$ At necropsy, asthmatic lungs typically show hyperinflation, mucus plugging in the airways, clusters of sloughed epithelial cells, and crystalline precipitates of eosinophil derived proteins. Bronchial mucosae are oedematous, the number of goblet cells is increased, the basement membrane is thickened, and the smooth muscle is hypertrophied. T cells, mast cells, eosinophils, and macrophages infiltrate the subepithelium, and the bronchi contain an inflammatory exudate in the bronchus itself. ${ }^{7}$

Although peribronchial inflammation and exaggerated bronchospastic responses are the pathological and physiological cornerstones of the asthmatic syndrome, the mechanisms underlying the initiation and maintenance of these processes remain poorly understood. It is most likely that different immunological processes mediate different aspects of asthma, and that various types of inflammatory responses contribute differentially to the multiple features manifested by patients with asthma. As a result, it has been difficult to design specific inflammation based therapeutic interventions for this disease.

Nevertheless, there is overwhelming evidence that CD4+ T helper cells are responsible for the orchestration of this complex immune reaction. In patients with asthma, CD $4+\mathrm{T}$ cells producing interleukin 4 (IL-4), IL-5, IL-9, and IL-13 (so called TH2 cytokines) have been identified in bronchoalveolar lavages (BAL) and airways biopsies. Because $\mathrm{TH} 2$ cytokines are required for the development of airway eosinophilia and IgE in mouse models, it has been proposed that $\mathrm{TH} 2$ cells stimulate an inflammatory response that results in asthma. ${ }^{8}$ In this review, we will focus on the evidence supporting the role of cytokines in general and the TH2 pathway in particular for asthma. Basically, two different approaches have contributed to highlight the involvement of cytokines. Experimental animal models have enabled the expression and function of individual cytokines to be assessed in vivo and have also allowed the efficacy of cytokine antagonism in asthma-like situations to be studied. In addition, human genetic studies have mainly helped shed some light on a series of candidate target genes encoding cytokines.

\section{Pathophysiology of asthma}

IgE AND MAST CELLS IN THE ACUTE PHASE OF ASTHMA

Similar to allergic rhinitis and atopic dermatitis, asthma is often accompanied by increased concentrations of circulating IgE. Genetic analyses of families have shown that BHR and IgE values are linked. ${ }^{9}$ Mast cells are thought to be the main link between IgE and BHR. Crosslinking of IgE bound to mast cells by FceRI triggers the release of preformed vasoactive mediators such as histamine, the synthesis of prostaglandins and leukotrienes, and the transcription of cytokines. In the bronchial mucosa, these mediators of immediate hypersensitivity reactions rapidly induce mucosal oedema, mucus production, and smooth muscle constriction, and eventually elicit an inflammatory infiltrate.

Quite surprisingly, it has been difficult to demonstrate a precise role for $\operatorname{IgE}$ in the pathogenesis of asthma using murine models of the disease. Inflammation of the bronchial mucosa and induction of BHR are elicited to the same extend in wild-type and $\operatorname{IgE}-/-$ mice subjected to repeated inhalations of allergen extracts of Aspergillus fumigatus. ${ }^{10}$ Even the syndrome of active anaphylaxis, with mast cell activation and mediator release, can be displayed by both ovalbumin (OVA) sensitised IgE-/- and FceRI-deficient mice after intravenous challenge with OVA. ${ }^{31}$ Although these findings point to the existence of parallel pathways of allergic reactions, they do not exclude an important role for IgE in allergic diseases in humans. The strong expression of hypersensitivity reactions in the absence of $\operatorname{IgE}$ might be species specific; in mice, the IgG1 isotype effectively sensitises mast cells and can passively confer hypersensitivity. Furthermore, in asthma, most animal analyses focused primarily on aspects of the disease that may be essentially cell driven, including eosinophil recruitment and BHR. It is possible that $\operatorname{IgE}$ plays a greater role in acute responses to inhaled allergen induced bronchospasm and late phase responses of the airways. ${ }^{23}$

Mast cells express approximately 300000 high affinity IgE receptors/cell, but aggregation of only 100 receptors is required for detectable responses. ${ }^{12}$ Histamine, the best studied of mast cell products, accounts for $5-10 \%$ of mast cell granule content, and is stored in association with proteoglycans. Histamine receptor stimulation results in smooth muscle contraction, increased vascular permeability, and prostaglandin generation. Chemotactic factors and neutral proteases (mainly tryptase) are the main other preformed mediators found in mast cell granules. Arachidonic acid metabolites, including prostaglandins $\left(\mathrm{PGD}_{2}\right)$ and leukotrienes $\left(\mathrm{LTC}_{4}\right)$, are another important group of mast cell derived mediators that are not stored 
but produced de novo after mast cell degranulation. $\mathrm{PGD}_{2}$ and $\mathrm{LTC}_{4}$ are potent bronchoconstrictors for human airways in vitro. ${ }^{12}$

Mast cell derived mediators have been found in lavage fluid from patients with asthma, supporting the role of these cells in the immediate or early allergic reaction in asthma. When allergen challenge preceded BAL, increases were documented for histamine, $\mathrm{LTD}_{4}, \mathrm{PGD}_{2}$, and tryptase. The role of mast cells in the late allergic response has been more difficult to resolve. However, they are thought to play a key role in the development of the chronic inflammatory phase through their production of cytokines and chemotactic factors that lead to the recruitment of other cell types such as eosinophils. ${ }^{3}$

EOSINOPHILS AS EFFECTORS OF THE LATE PHASE Even if the role of the eosinophil remains somewhat enigmatic, the current view is that it is a proinflammatory cell with a substantial tissue destructive potency. The biological activities exerted by the eosinophil are related to the products released from its granules, including the eosinophil cationic protein (ECP) and the major basic protein (MBP). These two potent cytotoxic proteins have the capacity to kill both mammalian and non-mammalian cells, such as parasites, by making pores in cell membranes, which leads to osmotic lysis. The accumulation and activation of eosinophils in the lungs are governed by the upregulation of adhesion molecules on lung endothelial cells and the production of various cytokines and chemotactic molecules by mast cells and T cells. Of these cytokines, IL-5 seems to play a central role, because it regulates most aspects of eosinophil behaviour, such as growth, apoptosis, adhesion, and secretion. ${ }^{13}$ Activation of the endothelium by cytokines such as IL-4 favours their migration to the lungs by upregulating the expression of vascular cell adhesion molecule 1 on endothelial cells. ${ }^{14}$ Finally, chemokines are responsible for tissue recruitment (see below).

EPITHELIAL CELLS AS GATEKEEPERS

Traditionally, the main function of airway epithelial cells was thought to be preventing the entry of noxious inhaled substances into the body and clearing particulates out of the airways. However, recent studies have demonstrated that these cells can synthesise and release several mediators that modulate the inflammatory effectors involved in bronchial asthma. Although the tracheobronchial epithelium comprises a variety of cell types, ciliated cells and goblet cells are the major components. Ciliated cells are the predominant cell type and are responsible for propelling the tracheobronchial secretions toward the pharynx. Airway epithelial cells can generate a wide variety of cytokines such as colony stimulating factors that promote the differentiation of inflammatory cells, or multifunctional factors that initiate and amplify inflammatory events. In addition, these cells contribute to the inflammatory response by the production of chemokines such as monocyte chemotactic protein 1
(MCP-1), RANTES, and others that recruit T cells and eosinophils.

Goblet cells, unlike ciliated epithelial cells, have electron dense granules containing mucin, the main component of mucus, which is responsible for effective ciliary beating and mucociliary clearance. Mucus hypersecretion contributes to the chronic symptoms associated with asthma, namely wheeze, cough, and sputum production. Mucins consist of a peptide backbone, to which multiple oligosaccharide side chains are bound, with carbohydrates accounting for $70-80 \%$ of the total mass of the mucin molecule. The complete mucin glycoprotein, which is highly sulphated, accumulates in secretory granules awaiting appropriate stimuli to be released.

At postmortem examination of the lungs of patients who died in status asthmaticus, bronchi and bronchioles are blocked or partially occluded with gelatinous plugs, consisting of mucus, plasma proteins, DNA, cells, and proteoglycans. Mucus hypersecretion in asthma is also illustrated by the sputum production that occurs during acute attacks or during recovery from an attack. Various mediators of airway mucus secretion are produced during the acute phase of asthma. The most potent inducers are inflammatory cell proteases, most notably mast cell chymase, neutrophil elastase, and cathepsin G. ${ }^{15} \mathrm{Cy}-$ tokines such as IL-1, IL-6 and tumour necrosis factor (TNF) might also be involved in this process. ${ }^{1617}$

AIRWAY SMOOTH MUSCLE CELLS AND AIRWAY REMODELLING

It is well recognised that contraction of the airway smooth muscle is the principal component underlying the bronchoconstriction that characterises the acute phase of an asthmatic attack. It is also well established that structural alterations are generated as a consequence of chronic inflammation and contribute to the symptoms and physiological dysregulation seen in asthma. Basically, all components of the airway wall have been reported to be thickened in asthma. Many elements contribute to this response, including an increase in airway smooth muscle, oedema, inflammatory cell infiltration, glandular hypertrophy, and connective tissue deposition. In particular, subepithelial fibrosis may be a major determinant of the pathway that leads to BHR. Cytokines of the transforming growth factor $\beta$ (TGF- $\beta$ ) family are thought to be involved in this process because they are produced in large quantities by eosinophils, fibroblasts, and epithelial cells, and are detected at increased concentrations in asthmatic BAL fluid before and after antigen challenge. Moreover, TGF- $\beta$ expression correlates with basement membrane thickness and disease severity. In transgenic animal models, overexpression of IL- 6 or IL-11 also results in subepithelial fibrosis. ${ }^{6}$ The mechanisms involved in the fibrotic process are not fully understood but might include a balance of matrix metalloproteinases (MMPs) and their inhibitors, the tissue inhibitors of metalloproteinases (TIMPs). In particular, 


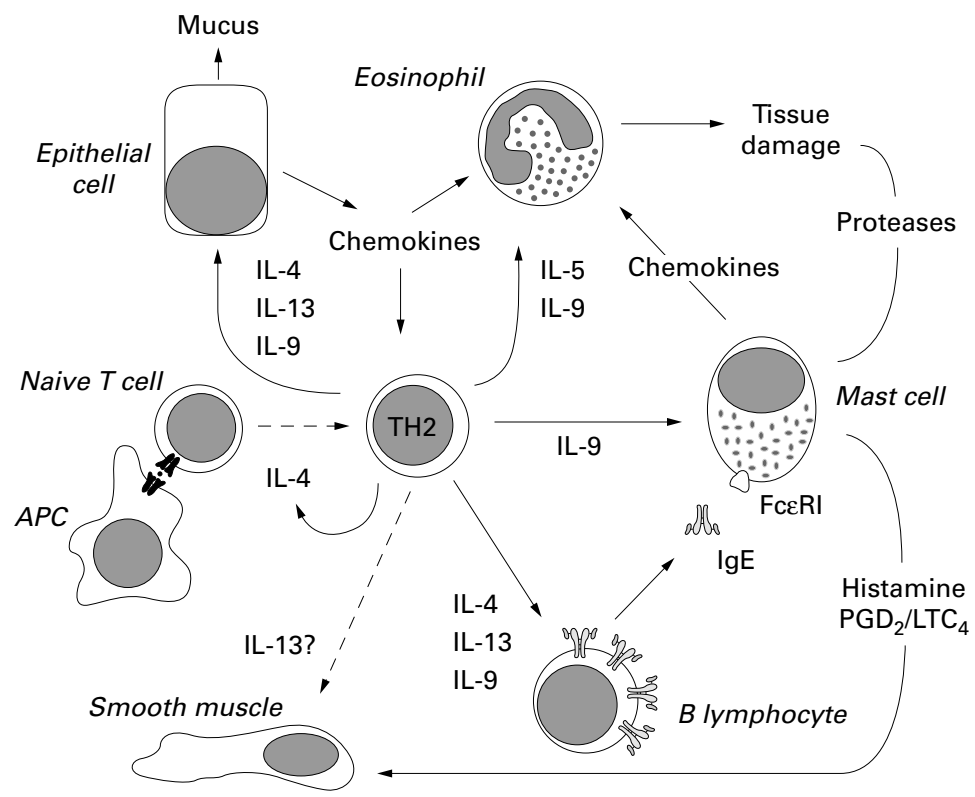

Figure 1 Pleiotropic activities of Thelper type 2 (TH2)-type cytokines in allergic asthma. Upon recognition of the antigen and activation by antigen presenting cells (APC), naive $T$ cells differentiate into TH2 cells, a process that is promoted by interleukin 4 (IL-4).

Activated TH2 cells stimulate B cells to produce IgE antibodies in response to $I L-4$, and to a lower extend to IL-13 or IL-9. IgE binds the high affinity IgE receptor at the surface of mast cells, the proliferation and differentiation of which is promoted by IL-9, in synergy. with other factors such as fibroblast derived mast cell growth factor. At contact with antigen, mast cells release the contents of their granules, including histamine, which will induce a bronchospasm, together with newly synthesised prostaglandins and leukotrienes $\left(\mathrm{PGD}_{2}\right.$ and LTC ). Mast cells also release chemotactic factors that contribute to the recruitment of inflammatory cells, particularly eosinophils, whose proliferation and differentiation from bone marrow progenitors is promoted by IL-5 and IL-9. Finally, epithelial cells upregulate their production of mucus and chemokines in responses to TH2 cytokines such as Il-4, IL-13, and IL-9. The presence of the IL-13 receptor at the surface of smooth muscle cells suggests that this factor can also directly affect smooth muscle contractility, but this remains to be demonstrated. patients with allergic asthma, TH2 lymphocytes are increased in the airways. ${ }^{20-22}$ Because TH 2 cells have been identified in the airways of patients with asthma, and because TH2 cytokines are required for the development of airway eosinophilia and IgE production, it has been proposed that TH2 cells trigger an inflammatory response that results in asthma.

The ability of TH2 cells to induce the characteristic features of asthma was recently shown in animal models by transferring $\mathrm{TH} 2$ cells into naive animals before antigen challenge. In this model, $\mathrm{TH} 2$ cells caused airway eosinophilia, mucus hypersecretion, and BHR. ${ }^{23} 24$ In addition, transgenic mice that overexpress $\mathrm{TH} 2$ cytokines in the airway epithelium exhibit typical inflammatory features of asthma, indicating that the activation of TH2 cells is sufficient for the induction of inflammation and the chronic pathological changes associated with asthma. Figure 1 is a representation of the $\mathrm{TH} 2$ orchestrated inflammatory network. In the next section, the activity of individual cytokines will be described in more detail, together with the potential therapeutic applications.

\section{Cytokines as therapeutic targets: lessons from mouse models}

Corticosteroids are the most effective treatment currently available for atopic diseases. New generation inhaled corticosteroids for asthma have a high level of anti-inflammatory action, with minimal side effects. The principal action of corticosteroids is to turn off multiple inflammatory genes, including those of cytokines, inflammatory enzymes, adhesion molecules, and inflammatory mediator receptors. Most of these effects can be related to the inhibition of transcription factors, such as AP-1, $\mathrm{NF}-\mathrm{AT}$, and $\mathrm{NF}-\kappa \mathrm{B}$. Alternative strategies aimed at the specific targeting of individual cytokines are currently under development. This includes cytokine antagonists such as antibodies, soluble receptors, or cytokine mutants, as well as drugs that would specifically interfere with the signal transduction pathways activated by these cytokines.

\section{IL-4 AND IL-13}

IL-4 was originally identified as a B cell growth factor, which drives the optimal stimulation of B cells by antigen. ${ }^{25}$ In addition, IL-4 stimulates the expression by $\mathrm{B}$ cells of major histocompatibility complex (MHC) class II molecules, B7-1 (CD80), B7-2 (CD86), CD40, surface IgM, and the low affinity $\operatorname{IgE}$ receptor, resulting in enhanced antigen presenting capacity of B cells. ${ }^{26}$ IL- 4 also induces the immunoglobulin isotype switch from $\operatorname{IgM}$ to $\operatorname{IgE} .^{27-30}$ In addition to its direct activity on IgE production, IL-4 promotes the development of $\mathrm{TH} 2$ responses by modulating the differentiation of $\mathrm{T}$ cells. Using in vitro priming models, it was shown that IL-4 is required for the generation of IL-4 producing $\mathrm{T}$ cells. ${ }^{26}$ Several lines of in vivo evidence support the importance of IL-4 priming for TH2-like responses. The $\mathrm{T}$ cell response of Leishmania 
major infected BALB/c mice was dominated by IL-4 producing clones, unless mice were treated with anti-IL-4 blocking antibodies. ${ }^{31}$ Furthermore, Nippostrongylus brasiliensis infected mice whose IL-4 gene has been disrupted by gene targeting show a five to 10 times reduction in IL- 5 production by $\mathrm{CD}_{4}^{+} \mathrm{T}$ cells in response to mitogens, compared with normal mice infected with $\mathrm{N}$ brasiliensis. ${ }^{32}$ Another potentially important activity of IL-4 in allergic inflammation is its ability to induce the expression of vascular cell adhesion molecule 1 on endothelial cells. This will produce enhanced adhesiveness of the endothelium for $\mathrm{T}$ cells, eosinophils, basophils, and monocytes, which is characteristic of allergic reactions. ${ }^{14}$

Because of these properties, IL-4 has long been considered as a potential target in allergies and asthma, and numerous in vivo studies highlighted its role in IgE production. ${ }^{30}{ }^{33}$ IL-4 transgenic mice have increased IgE values and allergic-like disease with ocular lesions infiltrated with mast cells and eosinophils. ${ }^{34}$ Analyses of mice with parasitic infections or treated with anti-IgD have confirmed the fundamental role of IL- 4 in the regulation of circulating IgE concentrations. ${ }^{33}{ }^{35}$ Anti-IL-4 antibody suppresses the eosinophilia, hyper$\mathrm{IgE}$, and intestinal mastocytosis found in helminth infections. ${ }^{36}$ Inactivation of the IL-4 gene in mice was associated with normal $\mathrm{T}$ and B cell development, but with a strong reduction of IgE values after infection with the nematode $N$ brasiliensis. ${ }^{37}$

However, it soon became clear that the role of IL-4 in IgE production could not be extended to airway hyperreactivity, which remains the hallmark of asthma. Overexpression of IL-4 in lungs leads to a lymphocytic and eosinophilic inflammation, but without airway hyperreactivity. ${ }^{38}$ Conversely, IgE and type I hypersensitivity mechanisms are not strictly required for airway obstruction. For example, mice completely deficient in antibody or B cells show an otherwise complete phenotype in an experimental asthma model. ${ }^{39} 40$ Thus, an essential effector role for IL-4 in experimental asthma has been difficult to show. Although IL-4 appears to play an important role in TH2 cell development and recruitment to the airways, ${ }^{23}{ }^{41} 42$ it is now generally accepted that this is not the case for the development of $\mathrm{BHR}$, at least in mouse models.

Nevertheless, it had been shown that IL-4 receptor (IL-4R) blocking antibodies inhibit allergen induced $\mathrm{BHR},{ }^{43}$ contrasting with the lack of effect of anti-IL-4 antibodies in the same model. Similar observations were obtained with IL- $4 \mathrm{R} \alpha$ deficient mice, which turned out to be much more resistant to the development of asthma than IL-4 deficient mice, ${ }^{44}$ suggesting that another IL- $4 \mathrm{R} \alpha$ interacting cytokine plays an important role in this model. The obvious candidate was IL-13, a cytokine closely related to IL- 4 , which binds to IL- $4 \mathrm{R} \alpha$ and is also expressed by TH 2 cells from patients with asthma. ${ }^{45}$ Overexpression of IL-13 in the lungs induces inflammation, mucus hypersecretion, subepithelial fibrosis, and eotaxin production, supporting the hypothesis that IL-13 is an important mediator of allergic asthma. ${ }^{46}$ In addition, intratracheal IL-13 administration was found to induce airway hyperreactivity, eosinophilia, and increased IgE production in a mouse model. ${ }^{44} 47$

Direct evidence for the role of IL-13 was provided by the observation that blocking its activity by intratracheal administration of soluble IL-13 receptor (IL-13R) reduced BHR and mucus production in a mouse model of asthma ${ }^{44}{ }^{47}$ Interestingly, this treatment did not seem to affect IgE production or eosinophilia, ${ }^{47}$ although the latter issue is controversial. ${ }^{44}$ The roles of IL-4 and IL-13 in eosinophilia have been studied in parasite infection models. In a pulmonary granuloma model, induced with Schistosoma mansoni eggs, it was found that eosinophil infiltration, in addition to IgE, and IL- 5 production, were reduced in both IL-4 or IL-13 deficient mice, but were abolished only in the combined absence of both cytokines. However, during $N$ brasiliensis infection, mice deficient in both IL-4 and IL-13 had raised IL-5 and eosinophilia. ${ }^{48}$ These observations suggest that IL-13 is not required for eosinophilia but can indirectly regulate this process, probably as a result of its ability to modulate the $\mathrm{TH} 1 / \mathrm{TH} 2$ balance, and particularly IL-5 production, but this might not be its primary role in experimental asthma models. Alternative candidate mechanisms for the effect of IL-13 include direct or indirect alterations in epithelial cells or smooth muscle function because IL-13 receptors have been detected recently on these cell types. ${ }^{49}$

Possible strategies to interfere with the IL-4IL-13 pathway include the use of inhibitory antibodies or soluble receptor domains. ${ }^{44450}$ One potential drawback of such inhibitors is the carrier effect, where a cytokine bound to another protein gains a much prolonged lifetime in the serum. For instance, soluble IL- $4 \mathrm{R}$ can block IgE production by neutralising endogenous IL-4, but it enhances the activity of exogenously administered IL-4, presumably by altering the biodistribution of the cytokine. ${ }^{51}$ In addition, soluble IL-4R transgenic mice were capable of mounting normal antigen specific IgE responses, despite the presence in serum of up to $3 \mu \mathrm{g} / \mathrm{ml}$ soluble receptor. $^{52}$ An alternative to such cytokine binding inhibitors is to use antagonistic cytokine mutants that retain the ability to bind to the receptor but fail to induce a signal. Such antagonists have been described for IL-4, with the most efficient human IL-4 antagonist described so far being [R121D,Y124D]-IL-4. ${ }^{53}$ A similar variant of mouse IL-4 was created by mutating the two structurally homologous amino acid residues, resulting in the variant [Q116D,Y119D]-mIL-4. This murine protein binds to IL-4R $\alpha$ with similar kinetics and affinity as the wild-type protein, but has no detectable biological activity because the second receptor subunit cannot be recruited. Most importantly, these antagonist mutants are competitive inhibitors for IL-4, and also for IL-13, because both cytokines need this chain for signal transduction. In vivo, treatment of 
mice with this IL-4 mutant prevented the development of OVA specific IgE and IgG1 antibodies, and led to failure to develop immediate cutaneous hypersensitivity or anaphylactic shock upon rechallenge. ${ }^{54}$

IL-5

The hallmark of IL-5 within the cytokine network is its limited spectrum of activity: it acts on B cells and eosinophils in the mouse, and seems to be restricted to eosinophils in humans. ${ }^{55}$ However, IL-5 is crucial in regulating the eosinophilic response both in vitro ${ }^{56}$ and in vivo, as seen during helminth infections. ${ }^{57}$ Transgenic mice in which IL-5 is constitutively expressed in all $\mathrm{T}$ cells show a profound and lifelong eosinophilia, with large numbers of eosinophils in the blood, spleen, and bone marrow. ${ }^{58}$ The generation of mice with an inactive IL-5 gene has confirmed the key role of IL-5 in the control of eosinophilia, both during parasite infections ${ }^{59}$ and when sensitised mice were challenged with an antigen aerosol. ${ }^{60}$ In this model, lung eosinophilia was absent and very little inflammation and lung damage was observed, providing an experimental rationale for the role of eosinophils in human asthma. In line with these observations, anti-IL- 5 antibodies decreased the eosinophil infiltration induced by OVA inhalation in the trachea of sensitised mice. ${ }^{61}$ The efficacy of anti-IL-5 antibodies on human eosinophils was also demonstrated in a model of ex vivo culture of nasal polyps from patients with allergic asthma. In this model, addition of anti-IL- 5 antibodies significantly accelerated eosinophil apoptosis, thereby decreasing tissue eosinophilia. ${ }^{62}$ However, whereas blocking IL-5 reduces eosinophil responses to allergen, this strategy falls short of inhibiting BHR, both in mouse experimental models $^{63}$ and in human preliminary observations. ${ }^{64}$ Thus, airway eosinophilia is not a requirement for allergen induced airway hyperresponsiveness. ${ }^{6566}$ Although blocking IL-5 might therefore fail to affect the acute phase of asthma, this approach could be an efficient way to interfere with long term airway remodelling, a process where eosinophils are thought to be crucial. Long term clinical studies are now in progress and should clarify the therapeutic benefit of IL-5 antagonism in asthma.

IL-9

IL-9 was originally identified as a growth factor for a subset of murine T cell clones. ${ }^{67}$ Its physiological role remained rather elusive until recently, when the combination of genetic studies and in vivo experiments shed some light on its potential role in allergic asthma.

IL-9 is a typical TH2 cytokine, both in vitro ${ }^{68}$ and in vivo. ${ }^{68}{ }^{69}$ In humans, analysis of IL-9 expression by peripheral $\mathrm{T}$ cells stimulated with anti-CD3 monoclonal antibodies unravelled a cascade of cytokines, with IL-2 being identified as a major mediator of IL-9 expression. ${ }^{70}$ IL-2 was required for IL-4 production, a combination of IL-2 and IL-4 for IL-10 production, and a combination of IL- 4 and IL-10 for IL-9 production. ${ }^{71}$ These observations pointed to IL-9 as an effector cytokine produced at the late stages of a $\mathrm{TH} 2$ response. However, in vivo, antigen induced production of IL-9 precedes IL- 4 expression, and is not modified in IL-4 deficient mice, ${ }^{72}$ indicating that, depending on the conditions, IL-9 could be either an early or a late effector of the $\mathrm{T}$ helper cell response. The central role played by IL-2 and IL-10 for IL-9 expression by human $\mathrm{T}$ cells was also confirmed in mouse models, because IL-9 production is significantly reduced in IL-2 deficient T cells, ${ }^{73}$ and in vivo in IL-10 targeted mice. ${ }^{72}$ In addition, IL- 1 and TGF- $\beta$ were also shown to be potent inducers of IL-9 production by murine peripheral $\mathrm{T}$ cells, ${ }^{73}{ }^{74}$ whereas IL-12, IFN- $\gamma$, and IFN- $\alpha / \beta$ inhibit IL-9 expression. ${ }^{75}$ In human asthma, expression of both IL-9 and its receptor was reported recently, and IL-9 mRNA expression correlated with the airway responsiveness to metacholine. ${ }^{77}$

Important information on IL-9 biology was provided by the analysis of transgenic mice overexpressing this cytokine, either systemically $^{78}$ or specifically in the lungs. ${ }^{79}$ IL-9 transgenic mice show an increase in pulmonary mast cell numbers. ${ }^{79} 80$ The activity of IL-9 on mast cells was originally discovered by Hültner and colleagues, who showed that this factor promotes, in synergy with IL-3, the proliferation of bone marrow derived mast cells (BMMC). ${ }^{81}$ Besides this growth promoting activity, IL-9 might play a key role in mast cell differentiation by regulating the expression of proteases. Stimulation of BMMC by IL-9 indeed induces the expression of transcripts encoding mast cell specific proteases mMCP-1, mMCP-2, mMCP-4, and granzyme B proteases, ${ }^{82} 83$ and IL-9 transgenic mice have increased circulating concentrations of mMCP-1. ${ }^{84}$ Moreover, IL-9 upregulates the mRNA expression of the $\alpha$ chain of the high affinity IgE receptor ${ }^{83}$ and induces IL-6 secretion by mast cell lines. ${ }^{81}$

Beside mast cells, accumulation of eosinophils has also been observed in BAL samples and in the peritoneal cavity of IL-9 transgenic mice.$^{79}{ }^{85} 86$ Although preliminary data indicate that IL-5 is required for the IL-9 induced eosinophilia in vivo (J-C Renauld et al, 2000, unpublished data), further experiments are needed to determine whether IL-9 has a direct or indirect effect on these cells. In addition, it seems that IL-9 can both promote the proliferation of eosinophil progenitors and indirectly induce their migration into the lungs, as suggested by the observation that IL-9 upregulates the expression of eotaxin and other chemokines by lung epithelial cells. ${ }^{85}$

The effect of IL-9 on immunoglobulin production, $\mathrm{IgE}$ in particular, remains poorly understood. Although IL-9 alone fails to stimulate Ig production in murine $\mathrm{B}$ cells in vitro, it synergises with suboptimal doses of IL-4 for the production of IgE and IgG1 by lipopolysaccharide (LPS) activated murine B cells. ${ }^{87}$ The influence of IL-9 on the IL-4 induced IgG1 production correlated with an increase in the number of IgG1 secreting cells. In contrast, IL-9 did not affect the IL-4 induced CD23 expression by LPS activated B 
cells, indicating that its activity is not a simple upregulation of the IL-4 responsiveness by B cells. In humans, very similar observations have been reported with peripheral B cells. ${ }^{88}$ Moreover, IL- 9 also potentiated the IL- 4 induced IgE production by sorted CD20+ human B cells upon costimulation by irradiated EL4 murine $\mathrm{T}$ cells, thereby suggesting a direct activity on B cells. ${ }^{88}$ In another experimental model, anti-IL-9 antibodies were found to inhibit IgE production by human peripheral blood mononuclear cells stimulated by IL- 4 and IL-7. ${ }^{89}$ In vivo, IL-9 transgenic mice show increased IgE production, ${ }^{86}{ }^{90}$ but it is not clear whether IL-9 specifically enhances the production of this isotype or whether this reflects a global increase in immunoglobulin values. In this respect, the observation that a special subset of B cells, called B-1 cells, was specifically activated and expanded in response to IL-9 in vivo, raises some intriguing questions about the role of this B cell population in allergies and IgE production. ${ }^{90}$

Mucus production is also stimulated by IL-9. ${ }^{91}$ In vitro, Basbaum and colleagues found that lung fluids from sensitised dogs stimulated mucin synthesis by human cultured epithelial cells, and that a large part of this effect was mediated by IL-9. ${ }^{92}$ Although the mechanisms involved in this effect are not fully understood, these authors could detect the IL-9 receptor both at the RNA and protein level in one epithelial cell line, suggesting that this cell type represents a new important target for IL-9. In addition, IL-9 stimulates mucin expression in vivo, either after intratracheal instillation ${ }^{92}$ or in IL-9 transgenic mice. ${ }^{91}$ Finally, IL-9 transgenic mice have greatly increased airway hyperresponsiveness, ${ }^{79} 86$ indicating that IL-9 overexpression induces a bona fide asthmatic phenotype.

The activity of IL-9 antagonism on the development of experimental asthma in the mouse has not been published yet, but preliminary data suggest that anti-IL-9 antibodies inhibit the induction of BHR, airway eosinophilia, and mucus overproduction in $A$ fumigatus sensitised mice (R Levitt, 2000, personal communication). Recent observations from parasitic infection models provide promising prospects. The immune response against helminth parasites shares many characteristics with allergies and asthma, including high $\operatorname{IgE}$ values, mast cells, and eosinophils. Mucosal mastocytosis is typically observed as a result of TH 2 cytokine production, including IL-9, during infection of mice by helminth parasites such as Trichuris muris. Systemic IL-9 overexpression also results in a massive intestinal mastocytosis and in increased circulating concentrations of mast cell specific proteases. ${ }^{80}$ Moreover, resistance of various mouse strains to $T$ muris infection correlated with the production of IL-9 in mesenteric lymph nodes, ${ }^{93}$ and IL-9 promotes the in vivo resistance to these parasites. ${ }^{94}$ The role of endogenous IL-9 was demonstrated recently by the vaccination of mice against their own IL-9, so that they produce anti-IL-9 blocking autoantibodies. $^{95}$ In the $T$ muris infection model, IL-9 vaccinated mice failed to mount an eosinophil response, indicating that IL-9 is a crucial factor for eosinophilia in vivo. In addition, these mice fail to expel the parasite, demonstrating that IL-9 is required for an efficient antiparasite response. ${ }^{95}$ The application of this anti-IL-9 vaccination strategy to experimental asthma should shed some light on the benefits that could be expected from IL-9 antagonists for patients with asthma.

\section{CHEMOKINES}

Chemokines are small secreted proteins, whose main (but not only) function is to regulate cell trafficking. They are classified into four subclasses: CC, CXC, C, and CX3C chemokines, based on the location of the first two cysteine residues in their sequence. To date, 23 human CC chemokines, 14 human CXC, and one each of the $\mathrm{C}$ and $\mathrm{CX} 3 \mathrm{C}$ chemokine subclasses have been described. ${ }^{96}$ The biological effects of chemokines are mediated by cell surface receptors, which belong to the superfamily of seven transmembrane $G$ protein coupled receptors. Like the chemokines themselves, the number of novel chemokine receptors has expanded rapidly. Nine CC chemokine receptors, five CXC chemokine receptors, one CX3C chemokine receptor, and one $\mathrm{C}$ chemokine receptor have been characterised, and several orphan putative chemokine receptors have been identified also. Interestingly, there is a certain degree of promiscuity in the chemokine superfamily, with many ligands binding different receptors and vice versa. ${ }^{96}$

The identification of eotaxin as the first chemokine with preferential ability to recruit eosinophils has drawn much attention to this molecule. ${ }^{97}$ Eotaxin was first discovered in the BAL fluid of guinea pigs after allergen challenge. ${ }^{98}$ Unlike other eosinophil chemotactic factors, eotaxin binds to a single receptor, CCR3, which is highly expressed on eosinophils. ${ }^{99} 100$ In addition to its chemotactic activity, eotaxin can induce increased binding of eosinophils under shear force to endothelium via $\beta 1$ and $\beta 2$ integrin mediated mechanisms. ${ }^{101}$ In human asthma, eotaxin is produced at high concentrations and localises in the airway epithelium. Several other chemokines including RANTES, MCP-3, and MCP-4 can also recruit eosinophils, probably through the CCR3 receptor, although these factors, but not eotaxin, bind other chemokine receptors. However, it is still not clear whether all of these chemokines contribute equally to in vivo eosinophil chemotaxis, or whether a specific chemokine mediates the bulk of the chemotactic activity and can be targeted for treatment. ${ }^{102} 103$

TH2 cells are probably also recruited to the lungs through various chemokines. Preferential chemokine receptor expression has been reported for $\mathrm{TH} 1$ and $\mathrm{TH} 2$ cells, the latter expressing greater amounts of CCR3, CCR4, and CCR8 ${ }^{104}$ However, other authors did not confirm the increased expression of CCR3 on $\mathrm{TH} 2$ cells, ${ }^{105}$ and this issue deserves further 
investigation. CCR8 might be another important target to interfere with $\mathrm{TH} 2$ cell recruitment based on its preferential expression on TH2 lymphocytes. ${ }^{106}$ CCR8 antagonists could also affect other processes in addition to $\mathrm{T}$ cell trafficking because I-309, the main CCR8 ligand, protects murine $\mathrm{T}$ cell tumours against corticoid induced apoptosis in vitro. ${ }^{107}$ Finally, neutralisation of $\mathrm{mMDC}$, a ligand for CCR4, in a model of lung inflammation resulted in prevention of airway hyperreactivity and in significant reduction of eosinophils in the lung interstitium but not in the airway lumen. ${ }^{108}$ These data suggest that $\mathrm{mMDC}$ is essential in the transit/retention of leucocytes in the lung tissue rather than in their extravasation from the blood vessel or during their transepithelial migration into the airways.

In addition to the initiation and maintenance of leucocyte accumulation, CC chemokine members might have the capacity to modulate $\mathrm{T}$ cell differentiation towards a $\mathrm{TH} 1$ type or TH2 type. ${ }^{102}$ In particular, MCP-1 can drive undifferentiated $\mathrm{T}$ cell populations towards an IL-4 producing TH2-type cell, whereas macrophage inflammatory protein $1 \alpha$ (MIP-1 $\alpha)$ appears to promote a TH1-type response by enhancing IFN- $\gamma$ and decreasing IL-4 production in vitro. ${ }^{109}$ Chemokines can also regulate antibody isotype switching to $\operatorname{IgE}$ in $\mathrm{B}$ cells. ${ }^{110}$ Although the biological relevance of these observations remains to be demonstrated in vivo, such observations supporting the role of chemokines in lymphocyte activation open some therapeutic options in asthma and allergies.

Because of its central role in eosinophil recruitment, and because of its expression on TH2 cells, the CCR3 chemokine receptor might be a good target to interfere with the development of asthma. Human RANTES was used as a CCR3 antagonist in a guinea pig model, taking advantage of the fact that the human ligand binds to, but does not activate, its guinea pig receptor. In this model, blocking CCR3 reduced eotaxin induced skin eosinophilia. ${ }^{111}$ Another elegant way to achieve this goal is illustrated by the use of met-RANTES, a variant of the RANTES chemokine, where addition of a single methionine residue at the $\mathrm{N}$-terminus of the protein resulted in a potent inhibitor of not only RANTES itself, but also of other CCR3 ligands. This antagonist can block $\left[\mathrm{Ca}^{2+}\right]_{\mathrm{i}}$ transients and actin polymerisation in eosinophils after in vitro stimulation with RANTES, MCP-3, and eotaxin. ${ }^{112}$ In vivo, met-RANTES significantly decreased lymphocyte and eosinophil infiltration as well as mRNA expression of eotaxin and RANTES in a murine asthma model. ${ }^{113}$ Interestingly, in this model, blockage of individual chemokines using specific antibodies reduced both lung leucocyte infiltration and BHR in a substantially different way. Thus, eotaxin neutralisation reduced BHR specifically and lung eosinophilia transiently after each antigen exposure, contrasting with previously mentioned studies where eosinophilia and BHR were differentially regulated. This discrepancy might result from additional activities of eotaxin or from the use of different experimental designs and/or distinct genetic backgrounds. MCP-5 neutralisation abolished BHR not by affecting the accumulation of inflammatory leucocytes in the airways, but by altering the trafficking of the eosinophils and other leucocytes through the lung interstitium. Finally, MCP-1 neutralisation greatly reduced BHR and inflammation, and this correlates with a pronounced decrease in monocyte and lymphocyte derived inflammatory mediators. ${ }^{113}$ Taken together, these observations suggest that chemokines work non-redundantly but in a coordinated manner, and that different molecules exacerbate airway hyperreactivity responses at specific stages of the evolving response. ${ }^{102}$

\section{Genetics of asthma: lessons from human models}

The relevance of the animal models described above is a source of endless controversy, and we should be extremely careful before making conclusions from a mouse experimental asthma model for the human disease. Although the human situation does not allow for the type of experimental manipulations undertaken in mice, much information on the pathogenesis of asthma could be provided by analysis of genetic variations that correlate with sensitivity to the disease. ${ }^{114115}$ In this respect, although it has long been known that asthma and related atopic diseases cluster in families, a major problem is the heterogeneity and intermittent nature of this disease and the lack of diagnostic precision. This has led to the use of intermediate phenotypes reflecting asthma and atopy, such as BHR, serum total and allergen specific IgE, skin prick test positivity, and circulating eosinophil counts. Although these provide quantitative measures, BHR - for example, can be assessed in many different ways, each measure describing different airway characteristics. The weakness of this approach is the assumption that the genetic basis of intermediate phenotypes will be the same as that of the disease state. Large epidemiological studies have established that the occurrence of asthma corresponds to high serum concentrations of total IgE. ${ }^{116}$ However, when analysed on a family basis, being a high IgE producer is only one factor related to the inheritance of asthma susceptibility and, in itself, had a limited predictive value for asthma inheritance. ${ }^{114}$

In contrast to single gene mutations, complex genetic traits such as asthma result from mild mutations in multiple genes, each of which has a small effect on the phenotype and requires subtle gene-gene or geneenvironmental interactions for optimal expression. Two fundamental approaches are being used to discover susceptibility genes in asthma and atopy: (1) linkage analysis with functional cloning and (2) association analysis for mutations of candidate genes thought to be involved in disease pathogenesis. ${ }^{114}$ Several genome wide screening studies have been published. Although there is an emerging consensus for some chromosomal regions in different populations, there are many where linkage has not 
been reproduced, probably because of genetic heterogeneity or environmental differences between populations, and because of low numbers of individuals investigated. At least four regions in the human genome-chromosomes 5q31-33, 6p21.3, 11q13, and 12q14.3-24.1contain genes consistently found to be associated with asthma, but several other regions (2q, $7,14,19 \mathrm{q} 13$, and 21q21) could also contain candidate genes. ${ }^{115} 117118$ As far as cytokines are concerned, chromosomes $5 \mathrm{q}$ and $12 \mathrm{q}$ are the most important loci. Other loci such as chromosome 11q13 (includes the $\beta$-chain of the high affinity IgE receptor), and chromosome 6 (encodes the MHC complex) have been reviewed recently, ${ }^{115117}{ }^{119}$ and will not be discussed here.

\section{CHROMOSOME 5q CYTOKINE CLUSTER}

The chromosome 5q31-33 region contains several genes that might be important in the development and progression of inflammation in asthma-genes encoding IL-3, IL-4, IL-5, IL-9, IL-13, granulocyte macrophage colony stimulating factor (GM-CSF), fibroblast growth factor 1 (FGF-1), and the $\beta$ chain of IL-12, as well as the gene encoding the $\beta$-adrenergic receptor. In a milestone study, Marsh et al searched for linkage between total serum IgE and markers at this locus in a population of 170 subjects from 11 Amish families. They found significant evidence for different markers and IgE values. ${ }^{120}$ Another study focusing on 538 individuals from 92 Dutch families showed evidence for linkage between $\mathrm{IgE}$ and markers at this locus, using a recessive model for inheritance of serum total IgE. ${ }^{121}$ Further analysis of this population showed that a two locus model fitted the inheritance of high serum IgE better than a one locus model, suggesting that at least two different genes are required for the expression of this trait, either on chromosome 5 or on another chromosome. ${ }^{122}$ In the same population, bronchial hyperresponsiveness was also linked to several markers on chromosome $5 .^{9}$ A Japanese study provided further supportive evidence for linkage between asthma and gene markers in or near the IL-4 and IL-9 genes on chromosome $5 \mathrm{q} 31-\mathrm{q} 33 .{ }^{123}$ Finally an association has been found between a polymorphism in the IL-9 gene, located in this region, and total $\operatorname{IgE}$ values in a random population from England. ${ }^{124}$

Two other genetic studies indirectly support the hypothesis that the IL-9 gene is at least partly responsible for the $5 \mathrm{q}$ linkage. First, a linkage to BHR and asthma has been demonstrated at the long arm XY pseudoautosomal region. ${ }^{125}{ }^{126}$ Interestingly, this genomic region is approximately $320 \mathrm{~kb}$ in size and contains the IL-9R gene. ${ }^{127}$ Another observation supporting the involvement of the IL-9 gene came from analysis of mouse models. Human chromosome $5 \mathrm{q} 31-33$ is known to be syntenic with segments of mouse chromosomes 11, 13, and 18 , with IL-4, IL-5, and IL-13 on mouse chromosome 11, and IL-9 on chromosome 13. Comparison of bronchial responsiveness in mice between hyporesponsive C57BL/6 and hyperresponsive DBA/2 mice showed that the difference between these strains is determined in part by a qualitative trait locus that maps to the syntenic region of chromosome 13. Moreover, bronchial hyporesponsiveness was associated with a greatly reduced capacity for IL-9 production by activated spleen cells, which was related to a genetic alteration at the $\mathrm{C} 57 \mathrm{BL} / 6$ locus. ${ }^{128}$ In humans, promoter polymorphism has been found for the IL-9 gene, ${ }^{129}$ but it is not clear so far whether this polymorphism greatly affects IL-9 transcription.

The IL-4 and IL-13 genes are localised within $25 \mathrm{~kb}$ on the proximal region of chromosome 5q31 and their linkage with asthma has been studied extensively over the past few years. At least five putative variants have been reported in the IL-4 promoter region but their importance for IL-4 production and IgE values remains controversial. ${ }^{129-132} \mathrm{Re}-$ cently, two variants of IL-13 have been identified in relation to asthma. One polymorphism is located in the promoter and correlates with IL-13 production. ${ }^{133}$ The other polymorphism is located in the coding sequence, inducing a charge change in the IL-13 protein (Gln110Arg), and was associated with asthma. ${ }^{49}$

The IL-4R $\alpha$ chain is an essential component of both the IL-4 and the IL-13 signal transduction pathway. Interestingly, a genetic linkage has been found between atopy and flanking markers to IL- $4 \mathrm{R}$ on chromosome $16 \mathrm{p} 12 .{ }^{134} \mathrm{At}$ least 12 common polymorphisms have been described in the coding region of the IL-4R gene, five of which lead to amino acid changes. ${ }^{114} 130135$ Surprisingly, depending on the studies, one particular variant (Gln576Arg) could be associated with low or high IgE values, possibly because of a linkage desequilibrium with another polymorphism of the same gene. ${ }^{130}$ An extracellular variant, Ile50Val has been identified in relation to atopic asthma in Japanese populations. ${ }^{136}$ Functional assays in transfected cell lines show that Ile50 upregulates cellular $\mathrm{IgE}$ synthesis as well as signal transducer and activator of transcription 6 (STAT6) activation, although this polymorphism did not significantly affect ligand binding affinity. ${ }^{136}$ Figure 2 shows a schematic representation of the IL-4-IL-13 signal transduction pathway. Finally, a non-coding variant of IL-13R $\alpha 1$ has been identified in association with total serum IgE in a UK population, ${ }^{49}$ reinforcing the hypothesis that subtle variations in the IL-4-IL-13 signal transduction pathway might affect the susceptibility to allergy.

Although cytokines are the major candidates for asthma susceptibility genes on chromosome 5q31-33, other genes from this region might also play an important role. Some studies have found abnormalities in the $\beta$-adrenergic receptor in patients with asthma. Several polymorphisms were described for this gene and one particular variant allowed the discrimination of a subset of patients with a distinct profile: they were more likely to be steroid dependent and followed a disadvantageous clinical course. ${ }^{137}$ CD14, a gene encoding one component of the LPS receptor, is another good candidate gene 


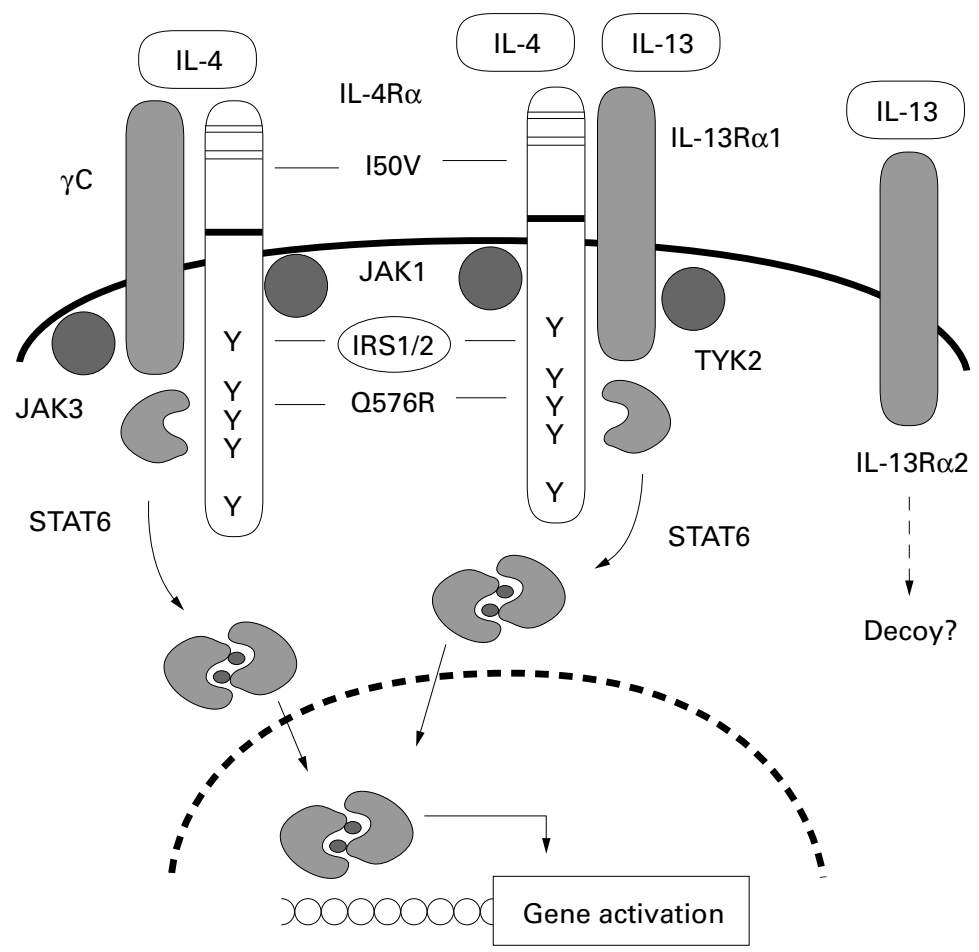

Figure 2 Signal transduction pathway and polymorphisms of the interleukin 4 (IL-4)/IL-13 receptors. IL-4 can bind to two distinct receptor complexes. On $T$ cells, the $I L-4$ receptor $(I L-4 R)$ consists of $\gamma C$, a transmembrane protein also shared by the $I L-2$, $I L-7, I L-9$, and $I L-15$ receptors, and IL-4Ra. On other cell types such as B cells, the IL-4R consists of IL-4Ra associated with IL-13Ra1. Tyrosine kinases FAK1 (Fanus kinase 1),

$\mathcal{F A K} 3$, and TYK2 are associated with the membrane proximal domain of these receptors as indicated in the figure. The thin and bold lines on the extracellular domain of IL-4Ra correspond to the four cystein residues and the WSXWS motif, respectively, which are the hallmarks of the haematopoietic receptor superfamily. Signal transduction through IL-4Ra involves activation of insulin receptor substrate 1/2 (IRS1/2) and signal transducer and activator of transcription 6 (STAT6), which lead to cell proliferation and gene activation, respectively. Crucial tyrosines of the intracytoplasmic domain of IL-4Ra are indicated. Genes activated by STAT6 include IgE, MHC II, and CD23. The two main IL-4Ra polymorphisms for which functional studies have suggested a biological relevance are indicated (I50V and G576R). IL-13 binds only to the second type of IL-4 receptor but is thought to activate the same downstream pathway. In addition, IL-13 binds to a distinct receptor, IL-13Ra2, which might be defective for signal transduction and act as a decoy receptor.

for asthma susceptibility. ${ }^{119}$ Baldini et al showed that a polymorphism of the CD14 gene is associated with soluble CD14 concentrations and with total serum IgE. ${ }^{138}$ Finally, other cytokine genes such as GM-CSF, the mast cell growth factor IL-3, and the $\beta$ chain of the TH1 promoting factor IL-12 could still contribute to the linkage of this locus on chromosome 5 . Taken together, all these observations suggest that there are too many good candidates in the 5q31-33 locus to explain the whole story with a single susceptibility gene. The role played by this region is more likely to be mediated by a combination of genes that share some common regulation features specific for this locus.

CHROMOSOME 12q14-24

The chromosome 12q14.3-24.1 region has been shown repeatedly in genome wide searches to contain a locus that affects asthma and atopy. ${ }^{114} 115119$ Interestingly, this region also coincides quite closely with a genetic linkage to inflammatory bowel disease. ${ }^{119}$ A study of 29 Afro-Caribbean families provided evidence for linkage to this region for both asthma and total serum IgE. ${ }^{139}$ Evidence of linkage with total IgE concentration was also seen in the Amish population already mentioned for the $5 \mathrm{q}$ cytokine cluster, ${ }^{120}{ }^{140}$ and this observation has been replicated by several groups. ${ }^{115} 141$

This region harbours possible candidate genes, particularly that encoding IFN- $\gamma$, the prototypical $\mathrm{TH} 1$ cytokine, which counteracts IL-4 in various systems. MGF, the ligand of $\mathrm{c}-\mathrm{Kit}$, is another attractive candidate because of its activity on mast cells. Interestingly, this region also contains the gene encoding STAT6, a crucial transcription factor for IL-4 and IL-13 signal transduction. Finally, new genes could also be identified in this region as potential candidates. In this respect, a new cytokine gene called IL-TIF/IL-22 and coding for an IL-10 related protein is located close to the IFN- $\gamma$ gene. ${ }^{142}$ Interestingly, this gene was originally identified as an IL-9 inducible gene in $\mathrm{T}$ cells and mast cells. ${ }^{143}$ More information on variants of these genes and their association with asthma are needed to define the respective roles of these candidate genes in asthma.

\section{TUMOUR NECROIS FACTOR}

TNF is a proinflammatory cytokine that is abundant in asthmatic airways. An association between TNF alleles (located on chromosome $6 \mathrm{p} 21.3$ ) and asthma has been observed. ${ }^{144}$ This association seemed independent of serum $\operatorname{IgE}$ or other measures of atopy, suggesting that it reflects the influence of inflammation rather than immunoregulation on the disease. However, in mouse models, TNF has been identified as a crucial component of IL-13 mediated TH2-type responses during helminth infections, ${ }^{145}$ indicating that this cytokine could exert pleiotropic activities in a complex syndrome such as asthma.

\section{CHEMOKINES}

Numerous polymorphisms have been described in chemokine receptor genes. ${ }^{102}$ The CCR5 $\delta 32$ mutation is directly related to altered human immunodeficiency virus (HIV) infectivity in human populations in vivo, whereas a CCR2 641 (a $\mathrm{G} \rightarrow \mathrm{A}$ substitution) also has an effect on the progression of HIV. ${ }^{146}$ These mutations may also have an effect on the incidence of other diseases, such as rheumatoid arthritis and diabetes mellitus. ${ }^{147}{ }^{148}$ Several polymorphisms have also been described in the CCR3 gene. ${ }^{102}$ It is surprising that these or other polymorphisms have not yet been reported to affect the prevalence or severity of asthma, and this issue deserves further investigation. Recently, a single nucleotide polymorphism has been described in the promoter region of the RANTES gene $(\mathrm{G} \rightarrow \mathrm{A}$ at position -403), and the mutant allele showed an eightfold increased transcriptional activity. ${ }^{149}$ The -403 A allele was associated with increased susceptibility to atopy, defined as skin test positivity, but not serum IgE concentrations. Homozygosity for this allele conferred a 6.5 fold increased risk of moderate/severe airway obstruction, a marker for established asthma. ${ }^{150}$ However, numbers of individuals in some groups of this study were small and this preliminary observation needs to be confirmed in larger cohorts. 


\section{Concluding remarks}

Both the experimental animal models and the human genetic studies point to a limited set of cytokines and cytokine receptors as crucial targets for the treatment of asthma, particularly IL-4, IL-5, IL-9, IL-13, some chemokines, and their respective receptors. Which cytokine is the best target remains to be determined, but it is tempting to speculate that the heterogeneity of asthma might reflect a heterogeneity of mechanisms and cytokines involved. Environmental differences might also affect the respective contributions of these cytokines in the disease. The experimental and genetic approaches described above have provided a wealth of valuable information but also have important limitations. The adequacy of the animal models regarding human asthma is an endless source of discussion. In addition, simply knowing which genes are associated with asthma will not reveal everything about the development of the disease or necessarily unmask the best therapeutic target. Absence of polymorphism does not infer absence of a crucial role in a particular pathway. Because of these limitations, it seems that only clinical trials will eventually validate the efficacy of antagonising the various cytokines.

However, additional genetic studies will offer a better understanding of full or partial resistance to treatment and progression into a more severe asthma phenotype, thereby allowing for the development of more effective medical treatment. The study of pharmacogenetics might be able to take advantage of genetic polymorphisms to predict the response of individuals to particular treatments. In the case of asthma, a mutation in the promoter region of the 5-lipooxygenase gene is associated with a lower response to a leukotriene antagonist, ${ }^{1141}$ supporting the notion that pharmacogenetics may open a way for better patient management. Similarly, a leukotriene C4 synthase polymorphism has been shown to be associated with increased risk of aspirin induced asthma, and might also predict the response to treatment. ${ }^{114}{ }^{152}$ There is little doubt that polymorphisms in cytokine or cytokine receptor genes will also be associated with distinct responses to asthma treatments.

The author thanks J Van Snick and $P$ Masson for helpful discussions and critical reading of the manuscript.

1 Cookson B. The alliance of genes and environment in asthma and allergy. Nature 1999;402:B5-11.

2 Holt PG, Macaubas C, Stumbles PA, et al. The role of allergy in the development of asthma. Nature 1999;402: B12-7.

3 Oettgen HC, Geha RS. IgE in asthma and atopy: cellular and molecular connections. F Clin Invest 1999;104:829-35.

4 Humbert M, Menz G, Ying S, et al. The immunopathology of extrinsic (atopic) and intrinsic (non-atopic) asthma: more similarities than differences. Immunol Today 1999;20 528-33.

5 Barnes PJ. Pathophysiology of asthma. In: Barnes PJ, Rodger IW, Thomson NC, eds. Asthma, basic mechanisms and clinical management. London: Academic Press, 1998: 487-506.

6 Elias JA, Zhu Z, Chupp G, et al. Airway remodeling in asthma. $\mathcal{F}$ Clin Invest 1999;104:1001-6.

7 Jeffery PK. Airway pathology in asthma. In: Barnes PJ, Rodger IW, Thomson NC, eds. Asthma, basic mechanisms Rodger IW, Thomson NC, eds. Asthma, basic mechanisms
and clinical management. London: Academic Press, 1998: 47-64.
8 Ray A, Cohn L. Th2 cells and GATA-3 in asthma: new Ray A, Cohn L. Th2 cells and GATA-3 in asthma: new
insights into the regulation of airway inflammation. 7 Clin insights into the regulation

9 Postma DS, Bleecker ER, Amelung PJ, et al. Genetic susceptibility to asthma-bronchial hyperresponsiveness coinherited with a major gene for atopy. $N$ Engl f Med 1995;333:894-900.

10 Mehlhop PD, van de Rijn M, Goldberg AB, et al. Allergeninduced bronchial hyperreactivity and eosinophilic inflammation occur in the absence of $\operatorname{IgE}$ in a mouse model of asthma. Proc Natl Acad Sci U S A 1997;94:1344-9.

11 Miyajima I, Dombrowicz D, Martin TR, et al. Systemic anaphylaxis in the mouse can be mediated largely through IgG1 and Fc gammaRIII. Assessment of the cardiopulmonary changes, mast cell degranulation, and death associated with active or IgE- or IgG1-dependent passive anaphylaxis. F Clin Invest 1997;99:901-14.

12 Scott T, Kaliner M. Mast cells in asthma. In: Kaliner MA Scott T, Kaliner M. Mast cells in asthma. In: Kaliner MA,
Metcalfe DD, eds. The mast cell in health and disease. New York: Marcel Dekker, 1993:575-608.

13 Venge P. Eosinophils. In: Barnes PJ, Rodger IW, Thomson NC, eds. Asthma, basic mechanisms and clinical management. London: Academic Press, 1998:141-58.

14 Moser R, Fehr J, Bruijnzeel PLB. IL-4 controls the selective endothelium-driven transmigration of eosinophils from allergic individuals. F Immunol 1992;149:1432-8.

15 Nadel JA. Role of mast cell and neutrophil proteases in airway secretion. Am Rev Respir Dis 1991;144:S48-51.

16 Levine SJ, Larivee P, Logun C, et al. Tumor necrosis factoralpha induces mucin hypersecretion and MUC-2 gene expression by human airway epithelial cells. Am $\mathcal{F}$ Respir Cell Mol Biol 1995;12:196-204.

17 Liu YC, Khawaja AM, Rogers DF. Pathophysiology of airway mucus secretion in asthma. In: Barnes PJ, Rodger cal management. London: Academic Press, 1998:205-27.

18 Wierenga EA, Snoek M, de Groot C, et al. Evidence for compartmentalization of functional subsets of CD2+ $\mathrm{T}$ lymphocytes in atopic patients. F Immunol 1990;144:46516.

19 Walker C, Virchow JC, Bruijnzeel PL, et al. T cell subsets and their soluble products regulate eosinophilia in allergic and nonallergic asthma. F Immunol 1991;146:1829-35.

20 Robinson DS, Hamid Q, Ying S, et al. Predominant TH2-like bronchoalveolar T-lymphocyte population in atopic asthma. N Engl F Med 1992;326:298-304.

21 Walker C, Bode E, Boer L, et al. Allergic and nonallergic asthmatics have distinct patterns of T-cell activation and cytokine production in peripheral blood and bronchoalveolar lavage. Am Rev Respir Dis 1992;146:109-15.

22 Wills-Karp M. Immunological basis of antigen-induced airway responsiveness. Annu Rev Immunol 1999;17:255-81.

23 Cohn L, Homer RJ, Marinov A, et al. Induction of airway mucus production by T helper 2 (Th2) cells: a critical role for interleukin 4 in cell recruitment but not mucus production. $\mathcal{E}$ Exp Med 1997;186:1737-47.

24 Cohn L, Tepper JS, Bottomly K. IL-4-independent nduction of airway hyperresponsiveness by Th2, but not Th1, cells. F Immunol 1998;161:3813-16.

25 Rabin EM, Mond JJ, Ohara J, et al. B cell stimulatory factor 1 (BSF-1) prepares resting B cells to enter $S$ phase in response to anti-IgM and lipopolysaccharide. $\mathcal{F} \operatorname{Exp} \mathrm{Med}$ 1986;164:517-31.

26 Seder RA, Paul WE. Acquisition of lymphokine-producing phenotype by CD4+ T cells. Anпu Rev Immunol 1994;12: $635-73$.

27 Coffman RL, Ohara J, Bond MW, et al. B cell stimulatory factor-1 enhances the IgE response of lipopolysaccharideactivated B cells. F Immunol 1986;136:4538-41.

28 Del Prete GF, Maggi E, Parronchi P, et al. IL-4 is an essential factor for IgE synthesis induced in vitro by human $T$ cell clones and their supernatants. F Immunol 1988;140: 4193-8.

29 Bacharier LB, Geha RS. Molecular mechanisms of IgE regulation. F Allergy Clin Immunol 2000;105:547-58.

30 Pene J, Rousset F, Briere F, et al. IgE production by normal human lymphocytes is induced by interleukin 4 and suppressed by interferons gamma and alpha and prostaglandin E2. Proc Natl Acad Sci U S A 1988;85:6880-4.

31 Heinzel FP, Sadick MD, Holaday BJ, et al. Reciprocal expression of interferon gamma or interleukin 4 during the resolution or progression of murine leishmaniasis. Evidence for expansion of distinct helper $\mathrm{T}$ cell subsets. $f$ Exp Med 1989;169:59-72.

32 Kopf M, Le Gros G, Bachmann M, et al. Disruption of the murine IL- 4 gene blocks Th2 cytokine responses. Nature 1993;362:245-8.

33 Finkelman FD, Holmes J, Katona IM, et al. Lymphokine control of in vivo immunoglobulin isotype selection. Annu Rev Immunol 1990;8:303-33.

34 Tepper RI, Levinson DA, Stanger BZ, et al. IL-4 induces allergic-like inflammatory disease and alters $\mathrm{T}$ cell development in transgenic mice. Cell 1990;62:457-67.

35 Finkelman FD, Katona IM, Urban JF, et al. IL-4 is required to generate and sustain in vivo IgE responses. F Immunol 1988;141:2335-41.

36 Urban J, Katona IM, Paul WE, et al. Interleukin-4 is important in protective immunity to a gastrointestinal nematode infection in mice. Proc Natl Acad Sci U S A 1991;88:551317.

37 Kuhn R, Rajewsky K, Muller W. Generation and analysis of interleukin-4 deficient mice. Science 1991;254:707-10.

38 Rankin JA, Picarella DE, Geba GP, et al. Phenotypic and physiologic characterization of transgenic mice expressing 
interleukin 4 in the lung: lymphocytic and eosinophilic inflammation without airway hyperreactivity. Proc Nat inflammation without airway hy

39 Hogan SP, Mould A, Kikutani H, et al. Aeroallergeninduced eosinophilic inflammation, lung damage, and airways hyperreactivity in mice can occur independently of IL-4 and allergen-specific immunoglobulins. $\mathcal{F}$ Clin Invest 1997;99:1329-39.

40 Corry DB, Grunig G, Hadeiba $\mathrm{H}$, et al. Requirements for allergen-induced airway hyperreactivity in $\mathrm{T}$ and $\mathrm{B}$ cell-deficient mice. Mol Med 1998;4:344-55.

41 Corry DB, Folkesson HG, Warnock ML, et al. Interleukin 4, but not interleukin 5 or eosinophils, is required in a murine model of acute airway hyperreactivity. 7 Exp Med 1996;183:109-17.

42 Brusselle G, Kips J, Joos G, et al. Allergen-induced airway inflammation and bronchial responsiveness in wild-type
and interleukin-4-deficient mice. Am 7 Respir Cell Mol Biol 1995; 12:254-9.

43 Gavett SH, O'Hearn DJ, Karp CL, et al. Interleukin-4 receptor blockade prevents airway responses induced by

44 Grünig $\mathrm{G}$, Warnock $\mathrm{M}$, Wakil $\mathrm{AE}$, et al. Requirement for IL-13 independently of IL-4 in experimental asthma. Science 1999;282:2261-3.

45 Corry DB. IL-13 in allergy: home at last. Curr Opin Immu nol 1999;11:610-14.

46 Zhu Z, Homer RJ, Wang Z, Chen Q, et al. Pulmonary expression of interleukin-13 causes inflammation, mucus hypersecretion, subepithelial fibrosis, physiologic abnormalities, and eotaxin production. I Clin Invest 1999;103: 779-88.

47 Wills-Karp M, Luyimbazi J, Xu X, et al. Interelukin-13: central mediator of allergic asthma. Science 1999;282: 2258-61.

48 McKenzie GJ, Fallon PG, Emson CL, et al. Simultaneous disruption of interleukin (IL)-4 and IL-13 defines individual roles in $\mathrm{T}$ helper cell type 2-mediated responses. $\mathcal{F}$ Exp Med 1999;189:1565-72.

49 Heinzmann A, Mao X, Akaiwa M, et al. Genetic variants of IL-13 signalling and human asthma and atopy. Hum Mol Genet 2000;9:549-59.

50 Borish LC, Nelson HS, Lanz MJ, et al. Interleukin-4 receptor in moderate atopic asthma. A phase $\mathrm{i} / \mathrm{ii}$ randomized, placebo-controlled trial. Am 7 Respir Crit Care Med 1999;160:1816-23.

51 Sato TA, Widmer MB, Finkelman FD, et al. Recombinant soluble murine IL-4 receptor can inhibit or enhance IgE responses in vivo. 7 Immunol 1993;150:2717-23.

52 Maliszewski CR, Morrissey PJ, Fanslow WC, et al. Delayed allograft rejection in mice transgenic for a soluble form of allograft rejection in mice transgenic for a soluble

53 Tony HP, Shen BJ, Reusch P, et al. Design of human interleukin-4 antagonists inhibiting interleukin-4-
dependent and interleukin-13-dependent responses in dependent and interleukin-13-dependent responses in T-cells and B-cells

54 Grunewald SM, Werthmann A, Schnarr B, et al. An antagonistic IL-4 mutant prevents type I allergy in the mouse: inhibition of the IL-4/IL-13 receptor system completely abrogates humoral immune response to allergen and development of allergic symptoms in vivo. F Immunol 1998;160 4004-9.

55 Sanderson CJ. Interleukin-5. In: Thomson A, ed. The cytokine

56 Sanderson CJ, Warren DJ, Strath M. Identification of a lymphokine that stimulates eosinophil differentiation in vitro: phokine that stimulates eosinophil differentiation in vitro: its relationship to $\mathrm{IL}-3$, and functional properties of 74 .

57 Coffman RL, Seymour BW, Hudak S, et al. Antibody to interleukin-5 inhibits helminth-induced eosinophilia in mice. Science 1989;245:308-10.

58 Dent LA, Strath M, Mellor AL, et al. Eosinophilia in transgenic mice expressing interleukin-5. F Exp Med 1990;172 1425-31.

59 Kopf M, Brombacher F, Hodgkin PD, et al. IL-5 deficient mice have a developmental defect in CD5+ B-1 cells and lack eosinophilia but have normal antibody and cytotoxic T cell responses. Immunity 1996;4:15-24.

60 Foster PS, Hogan SP, Ramsay AJ, et al. Interleukin-5 deficiency abolishes eosinophilia, airways hyperreactivity,
and lung damage in a mouse asthma model. $\mathscr{f}$ Exp Med 1996;183:195-201.

61 Nakajima H, Iwamoto I, Tomoe S, et al. CD4+ T-lymphocytes and interleukin- 5 mediate antigen-induced eosinophil infiltration into the mouse trachea. $A m$ Rev Respir Dis 1992;146:374-7.

62 Simon HU, Yousefi S, Schranz C, et al. Direct demonstration of delayed eosinophil apoptosis as a mechanism causing tissue eosinophilia. F Immunol 1997;158:3902-8.

63 Hogan SP, Matthaei KI, Young JM, et al. A novel T cell-regulated mechanism modulating allergen-induced airways hyperreactivity in $\mathrm{BALB} / \mathrm{c}$ mice independently of IL-4 and IL-5. F Immunol 1998;161:1501-9.

64 Barnes PJ. Therapeutic strategies for allergic diseases. Nature 1999;402:B31-8.

65 Tournoy KG, Kips JC, Schou C, et al. Airway eosinophilia is not a requirement for allergen-induced airway hyperresponsiveness. Clin Exp Allergy 2000;30:79-85.

66 Coyle AJ, Kohler G, Tsuyuki S, et al. Eosinophils are not required to induce airway hyperresponsiveness after nematode infection. Eur F Immunol 1998;28:2640-7.
67 Uyttenhove C, Simpson R, Van Snick J. Functional and structural characterization of $\mathrm{P} 40$, a mouse glycoprotein with T cell growth factor activity. Proc Natl Acad Sci US A 1988:85:6934-8.

68 Gessner A, Blum H, Röllinghoff M. Differential regulation of IL-9 expression after infection with leishmania major in susceptible and resistant mice. Immunobiology 1993;189: 419-35.

69 Svetic A, Madden KB, Di Zhou X, et al. A primary intestinal helminthic infection rapidly induces a gut associated elevation of TH2-associated cytokines and IL-3. F Immunol 1993;150:3434-41.

70 Houssiau F, Renauld J-C, Fibbe W, et al. IL-2 dependence of IL-9 expression in human $\mathrm{T}$ lymphocytes. $\mathcal{F}$ Immunol 1992:148:3147-51.

71 Houssiau F, Schandené F, Stevens M, et al. A cascade of cytokines is responsible for IL-9 expression in human T cells: involvement of Il-2, IL-4 and IL-10. F Immunol 1995; 154:2624-30.

72 Monteyne P, Renauld J-C, Van Broeck J, et al. IL-4independent regulation of in vivo IL-9 expression. F Immunol 1997;159:2616-23.

73 Schmitt E, Germann T, Goedert S, et al. IL-9 production of naive $\mathrm{CD} 4+\mathrm{T}$ cells depends on IL-2, is synergistically enhanced by a combination of TGF- $\beta$ and IL-4, and is inhibited by IFN $\gamma$. F Immunol 1994;153:3989-96.

74 Schmitt E, Beuscher U, Huel C, et al. IL-1 serves as a secondary signal for IL-9 expression. F Immunol 1991;147: 3848-54.

75 Lauwerys BR, Renauld J-C, Houssiau F. Inhibition of in vitro immunoglobulin production by IL-12 in murine graft-vs-host disease: synergism with IL-18. Eur 7 Immuno 1998;28:2017-24

76 Svetic A, Jian YC, Lu P, et al. Brucella abortus induces a novel cytokine gene expression pattern characterized by elevated IL-10 and IFN $\gamma$ in CD4+ cells. Int Immunol 1993; $5: 877-83$

77 Shimbara A, Christodoulopoulos P, Soussi-Gounni A, et al. IL-9 and its receptor in allergic and nonallergic lung disease: increased expression in asthma. $\mathcal{F}$ Allergy Clin Immunol 2000;105:108-15.

78 Renauld J-C, van der Lucht N, Vink A, et al. Thymic ymphomas in interleukin-9 transgenic mice. Oncogene 1994;9:1327-32.

79 Temann UA, Geba GP, Rankin JA, et al. Expression of interleukin-9 in the lungs of transgenic mice causes airway inflammation, mast cell hyperplasia, and bronchial hyperresponsiveness. $\mathcal{F}$ Exp Med 1998;188:1307-20.

80 Godfraind C, Louahed J, Faulkner H, et al. Intraepithelial infiltration by mast cells with both connective tissue-type and mucosal-type characteristics in gut, trachea and kidney of IL-9 transgenic mice. F Immunol 1998;160:3989-96.

81 Hültner L, Druez C, Moeller J, et al. Mast cell growth enhancing activity (MEA) is structurally related and functionally identical to the novel mouse $\mathrm{T}$ cell growth factor P40/TCGFIII (interleukin-9). Eur f Immunol 1990;20: 1413-16.

82 Eklund K, Ghildyal N, Austen F, et al. Induction by IL-9 and suppression by IL- 3 and IL-4 of the levels of chromosome 14-derived transcripts that encode late-expressed mouse and mast cell proteases. F Immunol 1993;151:426673.

83 Louahed J, Kermouni A, Van Snick J, et al. IL-9 induces expression of granzymes and high affinity $\operatorname{IgE}$ receptor in murine T helper clones. F Immunol 1995;154:5061-70.

84 Faulkner H, Humphreys N, Renauld J-C, et al. Interleukin-9 is involved in host protective immunity to intestinal nematode infection. Eur $\mathcal{F}$ Immunol 1997;27:2536-40.

85 Dong Q, Louahed J, Vink A, et al. IL-9 induces chemokine expression in lung epithelial cells and baseline airway eosinophilia in transgenic mice. Eur f Immunol 1999;29:2130-

86 McLane MP, Haczku AH, van de Rijn M, et al. Interleukin-9 promotes allergen-induced eosinophilic inflammation and airway hyperresponsiveness in transgenic mice. Am $\mathcal{F}$ Respir Cell Mol Biol 1998;19:713-20.

87 Petit-Frère C, Dugas B, Braquet $\mathrm{P}$, et al. Interleukin-9 potentiates the interleukin-4-induced IgE and IgG1 release from murine B lymphocytes. Immunology 1993;79:146-51.

88 Dugas B, Renauld J-C, Pène J, et al. Interleukin-9 potentiates the interleukin-4-induced immunoglobulin (IgG, IgM and $\operatorname{IgE}$ ) production by normal human B lymphocytes. Eur f Immunol 1993;23:1687-92.

89 Jeannin P, Delneste Y, Lecoanet-Henchoz S, et al. Interleukin-7 (IL-7) enhances class switching to IgE in the presence of T cells via IL-9 and SCD23. Blood 1998;91: presence $1355-61$.

90 Vink A, Warnier G, Brombacher F, et al. Interleukin-9induced in vivo expansion of the B-1 lymphocyte population. F Exp Med 1999;189:1413-23.

1 Louahed J, Toda M, Jen J, et al. Interleukin-9 upregulates mucus expression in the airways. Am f Respir Cell Mol Biol 2000;65:649-51.

92 Longphre M, Li D, Gallup M, et al. Allergen-induced IL-9 directly stimulates mucin transcription in respiratory epithelial cells. $\mathcal{F}$ Clin Invest 1999;104:1375-82.

93 Else KJ, Hultner L, Grencis RK. Cellular immune responses to the murine nematode parasite Trichuris muris. Immunology 1992;75:232-7.

94 Faulkner H, Renauld J-C, Van Snick J, et al. Interleukin-9 enhances resistance to the intestinal nematode Trichuris muris. Infect Immun 1998;66:3832-40. 
95 Richard M, Grencis RK, Humphreys NE, et al. Anti-Il-9 vaccination prevents worm expulsion and blood eosinophilia in Trichuris muris-infected mice. Proc Natl Acad Sci U S A 2000;97:767-72.

96 Homey B, Zlotnik A. Chemokines in allergy. Curr Opin Immunol 1999;11:626-34.

97 Corrigan CJ. Eotaxin and asthma: some answers, more questions. Clin Exp Immunol 1999;116:1-3.

98 Jose PJ, Adcock IM, Griffiths-Johnson DA, et al. Eotaxin cloning of an eosinophil chemoattractant cytokine and increased mRNA expression in allergen-challenged guineapig lungs. Biochem Biophys Res Commun 1994;205:788-94.

99 Heath H, Qin S, Rao P, et al. Chemokine receptor usage by human eosinophils. The importance of CCR3 demonstrated using an antagonistic monoclonal antibody. $\mathcal{F}$ Clin Invest 1997;99:178-84.

100 Daugherty BL, Siciliano SJ, DeMartino JA, et al. Cloning, expression, and characterization of the human eosinophil expression, and characterization of the human
eotaxin receptor. E Exp Med 1996;183:2349-54.

101 Kitayama J, Mackay CR, Ponath PD, et al. The C-C chemokine receptor CCR3 participates in stimulation of eosinokine receptor CCR3 participates in stimulation of eosino-
phil arrest on inflammatory endothelium in shear flow. $\mathcal{F}$ phil arrest on inflammatory end

102 Lukacs NW, Oliveira SHP, Hogaboam CM. Chemokines and asthma: redundancy of function or a coordinated effort. F Clin Invest 1999;104:995-9.

103 Teran LM. CCL chemokines and asthma. Immunol Today 2000;21:235-42.

104 Annuziato F, Galli G, Cosmi L, et al. Molecules associated with human Th1 or Th2 cells. Eur Cytokine Netw 1998;9:12-6.

105 Bonecchi R, Bianchi G, Bordignon PP, et al. Differential expression of chemokine receptors and chemotactic responsiveness of type $1 \mathrm{~T}$ helper cells (Th1s) and Th2s. F Exp Med 1998;187:127-34.

106 Zingoni A, Soto H, Hedrick JA, et al. The chemokine receptor CCR8 is preferentially expressed in Th2 but not Th1 cells. F Immunol 1998;161:547-51.

107 Van Snick J, Houssiau F, Proost P, et al. I-309/T cell activation gene-3 chemokine protects murine $\mathrm{T}$ cell lymphomas against dexamethasone-induced apoptosis. F Immunol 1996;157:2570-6.

108 Gonzalo JA, Pan Y, Lloyd CM, et al. Mouse monocytederived chemokine is involved in airway hyperreactivity and lung inflammation. I Immunol 1999;163:403-11.

109 Karpus WJ, Lukacs NW, Kennedy KJ, et al. Differential $\mathrm{CC}$ chemokine-induced enhancement of $\mathrm{T}$ helper cell cytokine production. F Immunol 1997;158:4129-36.

110 Kimata H, Yoshida A, Ishioka C, et al. RANTES and macrophage inflammatory protein 1 alpha selectively enhance immunoglobulin (IgE) and IgG4 production by human B cells. F Exp Med 1996;183:2397-402.

111 Marleau S, Griffiths-Johnson DA, Collins PD, et al. Human RANTES acts as a receptor antagonist for guinea pig eotaxin in vitro and in vivo. F Immunol 1996;157:4141pig

112 Elsner J, Petering H, Hochstetter R, et al. The CC chemokine antagonist met-RANTES inhibits eosinophil chemokine antagonist met-RANTES inhibits eosinophil effector functions through the chemokine rece

113 Gonzalo JA, Lloyd CM, Wen D, et al. The coordinated action of CC chemokines in the lung orchestrates allergic inflammation and airway hyperresponsiveness. $\mathcal{F}$ Exp Med 1998;188:157-67.

114 Holgate ST. Genetic and environmental interaction in allergy and asthma. F Allergy Clin Immunol 1999;104:113946.

115 Los H, Koppelman GH, Postma DS. The importance of genetic influences in asthma. Eur Respir f 1999;14:121027.

116 Burrows B, Martinez FD, Halonen M, et al. Association of asthma with serum IgE levels and skin-test reactivity to allergens. N Engl F Med 1989;320:271-7.

117 Ono SJ. Molecular genetics of allergy. Anпu Rev Immunol 2000;18:347-66

118 Cookson WOC, Moffatt MF. Genetics of asthma and allergic diseases. Hum Mol Genet 2000;9:2359-64.

119 Moffatt MF, Cookson W. Genetics of asthma and inflammation: the status. Curr Opin Immunol 1999;11:6069.

120 Marsh DG, Neely JD, Breazeale DR, et al. Linkage analysis of IL4 and other chromosome 5q31.1 markers and tota serum immunoglobulin E concentrations. Science 1994 264:1152-6.

121 Meyers DA, Postma DS, Panhuysen CI, et al. Evidence for a locus regulating total serum IgE levels mapping to chromosome 5. Genomics 1994;23:464-70.

122 Xu J, Levitt RC, Panhuysen CI, et al. Evidence for two unlinked loci regulating total serum IgE levels. Am f Hum Genet 1995;57:425-30.

123 Noguchi E, Shibasaki M, Arinami T, et al. Evidence for linkage between asthma/atopy in childhood and chromosome 5q31-q33 in a Japanese population. Am $\mathcal{F}$ Respir Crit Care Med 1997;156:1390-3.

124 Doull IJ, Lawrence S, Watson M, et al. Allelic association of gene markers on chromosomes $5 \mathrm{q}$ and $11 \mathrm{q}$ with atopy and
bronchial hyperresponsiveness. Am $\mathcal{F}$ Respir Crit Care Med 1996;153:1280-4.
125 Holroyd KJ, Martinati LC, Trabetti E, et al. Asthma and bronchial hyperresponsiveness linked to the XY long arm pseudoautosomal region. Genomics 1998;52:233-5.

126 Malerba G, Trabetti E, Patuzzo C, et al. Candidate genes and a genome-wide search in Italian families with atopic asthmatic children. Clin Exp Allergy 1999;29(suppl 4):2730 .

127 Kermouni A, Van Roost E, Arden KC, et al. The IL-9 receptor gene (IL9R): genomic structure, chromosomal localization in the pseudoautosomal region of the long arm of the sex chromosomes, and identification of IL9R pseudogenes at 9

128 Nicolaides NC, Holroyd KJ, Ewart SL, et al. Interleukin 9: candidate gene for asthma. Proc Natl Acad Sci US $A$ a candidate gene for

129 Rosenwasser LJ. Promoter polymorphism in the candidate genes Il-4, IL-9 TGF- $\beta 1$, for atopy and asthma. Int Arch Allergy Immunol 1999;118:268-70.

130 Shirakawa I, Deichmann KA, Izuhara I, et al. Atopy and asthma: genetic variants of IL-4 and IL-13 signalling. Immunol Today 2000;21:60-4

131 Burchard EG, Silverman EK, Rosenwasser LJ, et al. Association between a sequence variant in the IL- 4 gene promoter and FEV(1) in asthma. Am $\mathcal{F}$ Respir Crit Care Med 1999;160:919-22.

132 Rosenwasser LJ, Borish L. Genetics of atopy and asthma: the rationale behind promoter-based candidate gene studies (IL-4 and IL-10). Am 7 Respir Crit Care Med 1997;156: S152-5.

133 van der Pouw Kraan T, van Veen A, Boeije L, et al. An IL-13 polymorphism associated with increased risk of allergic asthma. Genes Immun 1999;1:61-5.

134 Deichmann KA, Heinzmann A, Forster J, et al. Linkage and allelic association of atopy and markers flanking the IL4-receptor gene. Clin Exp Allergy 1998;28:151-5.

135 Pan PY, Rothman P. IL-4 receptor mutations. Curr Opin Immunol 1999;11:615-20.

136 Mitsuyasu H, Yanagihara Y, Mao XQ, et al. Dominant effect of Ile50Val variant of the human IL-4 receptor alpha-chain in IgE synthesis. F Immunol 1999;162:1227-

137 Reihsaus E, Innis M, MacIntyre N, et al. Mutations in the gene encoding for the beta 2-adrenergic receptor in normal and asthmatic

138 Baldini M, Lohman IC, Halonen M, et al. A polymorphism in the 5' flanking region of the CD14 gene is associated with circulating soluble CD14 levels and with total serum immunoglobulin E. Am F Respir Cell Mol Biol 1999;20:97683.

139 Barnes KC, Neely JD, Duffy DL, et al. Linkage of asthma and total serum IgE concentration to markers on chromosome 12q: evidence from Afro-Caribbean and Caucasian populations. Genomics 1996;37:41-50.

140 Barnes KC, Marsh DG. The genetics and complexity of allergy and asthma. Immunol Today 1998;19:325-32.

141 The collaborative study on the genetics of asthma. A genome-wide search for asthma susceptibility loci in ethnically diverse populations. Nat Genet 1997;15:389-92

142 Dumoutier L, Van Roost E, Ameye G, et al. IL-TIF/IL-22: genomic organization and mapping of the human and mouse genes. Genes Immun 2000;1:488-94.

143 Dumoutier L, Louahed J, Renauld J-C. Cloning and characterization of IL-10-related T cell-derived inducible factor (IL-TIF), a novel cytokine structurally related to IL-10 and inducible by IL-9. F Immunol 2000;164:1814-9.

144 Moffatt MF, Cookson WO. Tumour necrosis factor haplotypes and asthma. Hum Mol Genet 1997;6:551-4.

145 Artis D, Humphreys NE, Bancroft AJ, et al. Tumor necrosis factor alpha is a critical component of interleukin 13-mediated protective T helper cell type 2 responses during helminth infection. F Exp Med 1999;190:953-62.

146 Locati M, Murphy PM. Chemokines and chemokine receptors: biology and clinical relevance in inflammation and AIDS. Anпи Rev Med 1999;50:425-40.

147 Garred P, Madsen HO, Petersen J, et al. CC chemokine receptor 5 polymorphism in rheumatoid arthritis. $f$ Rheumatol 1998;25:1462-5.

148 Szalai C, Csaszar A, Czinner A, et al. Chemokine receptor CCR2 and CCR5 polymorphisms in children with insulindependent diabetes mellitus. Pediatr Res 1999;46:82-4.

149 Nickel RG, Casolaro V, Wahn U, et al. Atopic dermatitis is associated with a functional mutation in the promoter of the C-C chemokine RANTES. F Immunol 2000;164:161216.

150 Fryer AA, Spiteri MA, Bianco A, et al. The $-403 \mathrm{G} \rightarrow \mathrm{A}$ promoter polymorphism in the RANTES gene is associated with atopy and asthma. Genes Immun 2000;1:509-14.

151 Drazen JM, Yandava CN, Dube L, et al. Pharmacogenetic association between ALOX5 promoter genotype and the response

152 Sanak M, Simon HU, Szczeklik A. Leukotriene C4 synthase promoter polymorphism and risk of aspirin induced asthma. Lancet 1997;350:1599-600. 